\title{
Survival of Spray-Dried Rhodotorula mucilaginosa Isolated from Natural Microbiota of Murta Berries and Antagonistic Effect on Botrytis cinerea
}

\author{
Alexandra González- \\ -Esparza ${ }^{1,2 *} \oplus$, Juan Carlos \\ Gentina' ${ }^{\top}$, Kong S. \\ Ah-Hen² ${ }^{\circledR}$, Roxana \\ Alvarado $^{3}{ }^{0}$, Joaquín \\ Stevenson ${ }^{2}$, Erika \\ Briceño ${ }^{4} \odot$ and Osvaldo \\ Montenegro ${ }^{4}$
}

'School of Biochemical Engineering, Faculty of Engineering, Pontifical

Catholic University of Valparaíso,

Avenue Brasil 2085, 2340000

Valparaíso, Chile

${ }^{2}$ Institute of Food Science and Technology, Faculty of Agricultural

Sciences, Austral University of Chile,

Avenue Julio Sarrazín sn, Campus Isla

Teja, 5090000 Valdivia, Chile

${ }^{3}$ Institute of Biochemistry and

Microbiology, Faculty of Sciences,

Austral University of Chile, Avenue

Julio Sarrazín sn, Campus Isla Teja,

5090000 Valdivia, Chile

${ }^{4}$ Institute of Plant Production and

Health, Faculty of Sciences, Austral

University of Chile, Avenue Eduardo

Tallman sn, Campus Isla Teja, 5090000

Valdivia, Chile

Received: 20 November 2018

Accepted: 26 March 2019

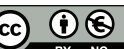

*Corresponding author:

Phone: +56989312256

E-mail: alexandra.gonzalez@gmail.com

\section{SUMMARY}

The aim of this study is to evaluate the survival rate and effective antagonistic activity against Botrytis cinerea, responsible for grey mould on harvested fruits and vegetables, of yeast Rhodotorula mucilaginosa, isolated and identified from the natural microbiota of murta (Chilean guava) berries, after spray drying at different inlet air temperatures, mass per volume ratio of encapsulating agent (maltodextrin) and feed flow rates. The $100 \%$ survival of the yeast was obtained after spray drying with $18 \%$ maltodextrin at $130^{\circ} \mathrm{C}$ inlet temperature and a feed flow rate of $9.25 \mathrm{~mL} / \mathrm{min}$. The dried yeast obtained under such conditions had the highest antagonistic activity in vitro and in vivo on apples, which showed that spray drying is a valid method to produce active dried cells of $R$. mucilaginosa that can be used for biocontrol of grey mould spoilage. It was also found that the encapsulating agent maltodextrin improved the in vitro antagonistic activity of $R$. mucilaginosa.

Key words: dehydration, yeast, grey mould, phytopathogenic fungus, antagonistic activity, biocontrol

\section{INTRODUCTION}

Botrytis cinerea is a phytopathogenic fungus responsible for grey mould spoilage of many fruit and vegetable products around the world (1). It is a latent postharvest hazard that can provoke spoilage of fruit and vegetable products during storage and transport, when unfavourable conditions, such as physical damage, cellular senescence or high relative humidity of air, may occur and increase the vulnerability of vegetable products (1-3). The main strategy to control postharvest diseases is still through the use of chemical fungicides (4). However, their application is associated with many drawbacks and can induce fungicide resistance in pathogens $(5,6)$, affect the biota via toxic mechanisms, accumulate in living organisms or in underground water, have harmful effect on human health or cause environmental pollution (6). Due to a high genetic variability, a short life cycle and a prolific reproduction, B. cinerea is considered a highly hazardous pathogen that develops resistance to chemical fungicides (7), especially if applied too frequently (1). This is one of the main reasons for the emergence of biocontrol agents that are being applied as biological and natural alternatives to chemical fungicides in reducing disease incidence provoked by phytopathogens in vegetable products (8-11).

The biocontrol agents are mostly living microorganisms (12) used to counteract the effect of pathogens on the plants by reducing their growth and activity, thus preventing development of diseases that cause huge financial loss in the agricultural sector $(9,10)$. Yeasts stand out as biocontrol agents against pathogens in many agricultural products, due to their versatile characteristics, such as genetic stability, safe application, wide antagonistic range (11), tolerance to extreme pre- and postharvest conditions, high adaptability to vegetable microenvironment, and rapid growth on complex and cheap substrates in fermentors, which all leads to easy production in large quantity $(13,14)$. Among the yeast species that have proved to be effective against various pathogens, including $B$. cinerea, the following can be mentioned among others: Metschnikowia fructicola against Penicillium expansum 
(15), Candida oleophila against P. expansum and B. cinerea (16), Pichia guilliermondii against B. cinerea (17) or Pichia membranifaciens against Colletotrichum gloeosporioides (18). This has led to the development of many commercial products for application within a biological control strategy against plant pathogens, which have been registered in countries of the European Union (Germany, Spain) and Israel (19). Many other yeast species have also been studied and have shown biocontrol activity against postharvest diseases; however, their development to a commercial product has not been achieved, due to low efficiency and stability and failure to meet the requirement for application on vegetable crops (3). Moreover, from a commercial standpoint high yield and high antagonistic efficiency depend on a strict monitoring of production, formulation and stabilization of the microorganisms during packing, storage and application (19). Frequently, the microbial biocontrol agents are found active in liquid formulations, which have the main disadvantage of large volume and require refrigeration during storage and transport (20). Therefore, to enable the development of a stable commercial product, the liquid formulations must be submitted to a drying process that does not affect the biocontrol activity of the fresh cells (21). Various drying processes have been applied, among others, freeze drying of Candida sake CPA-1 (22), Pichia anomala J121 (23,24), Cryptococcus laurentii and Rhodotorula glutinis $(25,26)$, fluidized bed drying on Cryptococcus flavescens OH 182.9 (27), P. anomala J121 (24) and Aureobasidium pullulans (28) and spray drying on C. sake CPA-1 $(20,21)$. Freeze drying is considered the most appropriate and least harmful method to dry microorganisms (24); nonetheless, it is a high-cost process with long drying time and high energy consumption (29). On the other hand, spray drying is the main drying process used on an industrial scale (29-32), due to its high production rate and low operation cost $(33,34)$. However, the survival rate of the microorganisms during spray drying is generally very low and measures must be taken to protect them (35). Therefore, we conducted assays to assess the effect of spray drying on survival rate and effective antagonistic activity of Rhodotorula mucilaginosa yeast in vitro and in vivo against $B$. cinerea, identified in the natural microbiota of murta (Chilean guava) berries. The spray drying was evaluated at different inlet air temperatures, mass per volume ratios of maltodextrin as encapsulating agent and feed flow rates.

\section{MATERIALS AND METHODS}

\section{Microorganisms and their preparation for antagonistic assays}

Rhodotorula mucilaginosa was isolated from the surface of fresh murta (Ugni molinae Turcz) berries, obtained in the neighborhood of Curanilahue, in the Province of Arauco, Region of Biobío, Chile $\left(37^{\circ} 28^{\prime} \mathrm{S}, 73^{\circ} 21^{\prime} \mathrm{W}\right)$. It was initially unidentified among around 168 yeast strains obtained from the surfaces of different plants in a preliminary study on biofungicidal control of grey mould. The yeast was selected due to its vigorous growth and its origin from the native Chilean guava (murta) berries. It was kept in glycerol (Calbiochem, San Diego, CA,
USA) mixed with diluted yeast extract-peptone-dextrose (YPD) broth (yeast extract $2 \mathrm{~g} / \mathrm{L}$, peptone $4 \mathrm{~g} / \mathrm{L}$ and dextrose $4 \mathrm{~g} / \mathrm{L}$; Becton Dickinson and Company, Franklin Lakes, NJ, USA), adjusted to $\mathrm{pH}=6.0$ and maintained at $-20{ }^{\circ} \mathrm{C}$ until use in the antagonistic assays. To prepare the yeast culture for the assays, it was first reactivated in $20 \mathrm{~mL}$ of diluted YPD broth in a $100-\mathrm{mL}$ conical flask and incubated at $30^{\circ} \mathrm{C}$ on a shaker (IS-971; Lab Companion, Seoul, Republic of Korea) at 200 rpm for 22 $h$. The preculture of the yeast was then inoculated in diluted YPD broth to a total volume of $200 \mathrm{~mL}$ and further incubated under the same conditions.

Grey mould Botrytis cinerea was isolated from the surface of infected murta berries. The culture was maintained at $4{ }^{\circ} \mathrm{C}$ on potato dextrose agar (PDA; Becton Dickinson and Company) until use in the antagonistic assays, when they were first incubated for 7 days at $25^{\circ} \mathrm{C}$ on PDA. The suspensions of $B$. cinerea spores required for the antagonistic assays were then prepared by adding sterile water to the sporulating edges of the culture and separating the mycelium from the spores by filtration through four layers of sterile cotton gauze. Spore count was determined using the Neubauer chamber.

\section{Identification of antagonistic yeast found on murta berries}

To identify the yeast $R$. mucilaginosa, 5.8S internal transcribed spacer, ITS1-5.8s-ITS2, was first amplified using polymerase chain reaction (PCR). Total DNA was extracted using the extraction kit E.Z.N.A. ${ }^{\circledR}$ Fungal DNA Mini Kit (Omega Bio-tek, Inc., Norcross, GA, USA). The primers used were: 5'-TCCGTAGGTGAACCTGCGG-3' for ITS1 and 5'-TCCTCCGCTTATTGATATGC-3' for ITS4. The PCR operating conditions were: $95^{\circ} \mathrm{C}$ for 2 min denaturation; 30 thermal cycles comprising $30 \mathrm{~s}$ at $95^{\circ} \mathrm{C}, 30 \mathrm{~s}$ at $56.8^{\circ} \mathrm{C}$ annealing temperature and $1 \mathrm{~min}$ at $72^{\circ} \mathrm{C} ; 2 \mathrm{~min}$ at $72^{\circ} \mathrm{C}$ and finally $5 \mathrm{~min}$ at $4^{\circ} \mathrm{C}$. The PCR product was excised from the agarose gel and purified with Wizard ${ }^{\circledR}$ SV Gel and PCR Clean-Up System (Promega, Madison, WI, USA). The DNA sequencing was done by Macrogen, Inc. (Seoul, Republic of Korea). The obtained nucleotide sequence was identified by comparison with available nucleotide sequences of the GenBank (36), using the Basis Local Alignment Search Tool (BLAST) algorithm (37).

\section{Spray drying, survival rate, moisture content and yeast powder yield}

The spray drying was performed using the laboratory scale spray dryer (SD-Basic; Lab Plant, Hunmanby, UK). Assays were conducted at two inlet temperatures $\left(130\right.$ and $\left.140^{\circ} \mathrm{C}\right)$, using two feed flow rates ( 6.30 and $9.25 \mathrm{~mL} / \mathrm{min})$ and 18 and $26 \%$ maltodextrin (PRINAL, Santiago, Chile) as encapsulating agent. $R$. mucilaginosa yeast cells were first centrifuged (Himac CR 21G II; Hitachi, Tokio, Japan) at $6000 \times g$ and $4{ }^{\circ} \mathrm{C}$ for 6 min and then resuspended in sterile distilled water with the corresponding mass of maltodextrin to obtain the suspension that was then dried in the spray dryer. In each assay survival rate, moisture content and yeast powder recovery yield were determined. 
Survival rate was determined as a percentage of living yeast cells in the dried powder with respect to the living yeast cells in the initial feed suspension before spray drying:

$$
\text { Survival rate }=\left(N_{\mathrm{p}} / N_{\mathrm{s}}\right) \cdot 100
$$

where $N_{\mathrm{p}}$ and $N_{\mathrm{s}}$ are yeast cell counts in the dried powder and in the feed suspension respectively, expressed as living cells per $\mathrm{g}$ of dry matter. Yeast cell count was determined using plate count method on PDA. Survival rate can also be expressed in terms of decimal reduction $(20,21)$ as follows:

$$
\text { Survival rate }=105.07 \cdot \mathrm{e}^{2.3035 \log \left(\mathrm{N}_{\mathrm{p}} / \mathrm{N}_{\mathrm{s}}\right)}
$$

Moisture and dry matter contents were determined in $1 \mathrm{~g}$ of the spray-dried powder or in $1 \mathrm{~mL}$ of the feed suspension using a convective oven (ZRD A5055; Zhicheng, Shangai, PR China) at $105^{\circ} \mathrm{C}$ for $24 \mathrm{~h}$. Yeast powder yield was calculated as a percentage of the dry matter in the spray-dried yeast powder to dry matter in the feed suspension.

\section{Determination of in vitro antagonistic activity}

The antagonistic activity of the yeast was determined according to the method described by Zhang et al. (38) with some modifications. The PDA plate with a centred well of 12 $\mathrm{mm}$ in diameter was prepared by first pouring $10 \mathrm{~mL}$ of sterile PDA on a $90 \mathrm{~mm} \times 15 \mathrm{~mm}$ Petri dish. After solidification, a sterile $12-\mathrm{mm}$ plastic ring was placed in the centre of the dish before pouring another $25 \mathrm{~mL}$ of PDA. The ring was removed before inoculation with $100 \mu \mathrm{L}$ of yeast suspension ( $10^{7}$ cells/ $\mathrm{mL}$ ) obtained from fresh or dried cells. The samples of yeast suspension were taken at the stationary phase from $200 \mathrm{~mL}$ of diluted YPD culture broth of the fresh or the reactivated dehydrated yeast cells of R. mucilaginosa. In the control well, $100 \mu \mathrm{L}$ of sterile water were added. After $2 \mathrm{~h}, 100 \mu \mathrm{L}$ of the $B$. cinerea suspension, containing $10^{5} \mathrm{spores} / \mathrm{mL}$, were added and incubated at $28^{\circ} \mathrm{C}$ for 5 days, after which the colony diameter of $B$. cinerea was measured.

\section{Determination of in vivo antagonistic activity}

The in vivo antagonistic activity of spray-dried R. mucilaginosa against $B$. cinerea on apples was assayed using the samples with the best survival rate. For the assays, three sets of 40 apples were used; one set, treated with a commercial biocontrol agent (Trichonativa ${ }^{\circledR}$, Bio Insumos Nativa SPA, Talca, Chile) based on Trichoderma spp. and B. cinerea served as a control, the second set was inoculated only with $B$. cinerea and the third set was inoculated with both $R$. mucilaginosa and $B$. cinerea. Before the assays, the apples were first disinfected by spraying with $70 \%$ aqueous ethanol (Winkler Ltda., Santiago, Chile) and then dipped in $1 \%$ sodium hypochlorite solution (Winkler Ltda.) for $1 \mathrm{~min}$, followed by thorough rinsing with sterile water for $5 \mathrm{~min}$. For the assays, the disinfected apples were punctured at three equidistant spots on the equatorial line to cause three wounds of $2 \mathrm{~mm}$, then inoculated with $10 \mu \mathrm{L}$ of a suspension of R. mucilaginosa $\left(10^{7}\right.$ cells $/ \mathrm{mL}$ ) or Trichoderma spp. $\left(10^{9} \mathrm{CFU} / \mathrm{mL}\right)$ and left to dry in a laminar flow cabinet (AHC-4D; ESCO, Singapore) for 2 h. Afterwards, the apples were inoculated with $10 \mu \mathrm{L}$ of a $B$. cinerea suspension $\left(10^{6}\right.$ spores $/ \mathrm{mL}$ ) and incubated in humidity chamber (38) consisting of a closed plastic box to maintain a high relative humidity (about $95 \%$ ) and incubated at $(18 \pm 2){ }^{\circ} \mathrm{C}$ for 10 days. Antagonistic activity was determined by measuring the diameter of the lesion.

\section{Statistical analysis}

The data acquired in triplicate were analyzed by a one-way analysis of variance (ANOVA) using the statistical software Statgraphics Centurion XVI.II (Statistical Graphics Corp., Herndon, VA, USA) for three factors (inlet temperature, maltodextrin mass per volume ratio and feed flow rate) at two levels, with a total of 24 assays $\left(2^{3} \times 3\right)$. Normality and homogeneity of variance were analyzed using respectively the Shapiro-Wilk and Levene tests. The Kruskal-Wallis test was applied for non-compliance analysis of mean values.

\section{RESULTS AND DISCUSSION}

\section{Identification of the antagonistic yeast}

Most antagonistic microorganisms used in the biocontrol of postharvest diseases come from natural sources, usually from the microbiota on fruit and vegetable surfaces, which are then isolated, reproduced and prepared for application on the products infected by the pathogen $(8,13,39)$. In this study, the antagonistic yeast for biocontrol of grey mould Botrytis cinerea, isolated from the surface of murta berries, was identified as Rhodotorula mucilaginosa (NCBI accession number KM822749.1). This yeast species had previously been isolated in different parts of the world from surfaces of peaches and apples and its antagonistic activity has also been evaluated satisfactorily against several phytopathogenic moulds, including $P$. expansum, Rhizopus stolonifer and $B$. cinerea, reducing the incidence of the corresponding diseases (40-45). Howev$\mathrm{er}$, the R. mucilaginosa isolated from the Chilean native murta berries has not been investigated so far and our results have shown its promising potential for biocontrol of grey mould.

\section{Results of spray drying}

The spray drying considered three independent variables (inlet air temperature, mass per volume ratio of maltodextrin as encapsulating agent and feed flow rate), and the effects of drying on the yeast $R$. mucilaginosa were evaluated in terms of three response variables, namely survival rate, moisture content and yeast powder yield. As expected, the temperature profile during drying depended on the inlet air temperature and feed flow rate that defined the residence time within the dryer. Therefore, the lowest survival rate of the yeast was at 
the highest inlet air temperature and the lowest feed flow rate (Table 1), with the lowest moisture content of the powdered product (Fig. 1). It was also observed that all three variables had a combined effect on the outlet temperature (Table 1). Higher content of maltodextrin and higher feed flow rate implied a higher content of the total mass of solid and liquid, leading to higher thermal capacity. Consumption of the initial thermal load, determined by inlet air temperature, by more solids reduced the availability of energy used up as latent heat of vapourization, leading to lower removal of water. Moreover, as feed flow rate increased, residence time tended to decrease, resulting in a higher outlet temperature and lower removal of moisture. Higher moisture content of the powdered product leads to a lower yeast survival rate due to its higher susceptibility to temperature $(21,30)$.

\section{Yeast survival rate}

As can be seen in Table 1, the highest survival rate (113.6 $\%)$ of dried powdered yeast was observed at an inlet temperature of $130{ }^{\circ} \mathrm{C}, 18 \%$ encapsulating agent and a feed flow of $9.25 \mathrm{~mL} / \mathrm{min}$. The Kruskal-Wallis test applied to the survival data in an analysis of median showed that significant differences $(p<0.05)$ exist among the determined survival rates. All three process parameters have significant effects. Survival rate was the highest at high feed flow, low temperature and low mass per volume ratio of maltodextrin. When the inlet temperature was increased to $140^{\circ} \mathrm{C}$, the most favourable survival rate was achieved with the lower mass per volume ratio of maltodextrin (18\%) and higher feed rate $(9.25 \mathrm{~mL} / \mathrm{min})$ (Table 1). Different processing and biological factors have been reported to affect cell viability. The main process parameters include outlet air temperature, residence time and feed flow rate $(31,46)$, while the biological factors may include genus, species or strain of the dehydrated microorganisms (31). The outlet temperature during spray drying depends on residence time, which in turn depends on the inlet air temperature and feed flow rate (31). In this respect, various research works have considered the use of spray drying on yeasts (Table $2(20,21,35,47,48))$. In two studies $(20,21)$, C. sake CPA-1, a known postharvest biocontrol agent

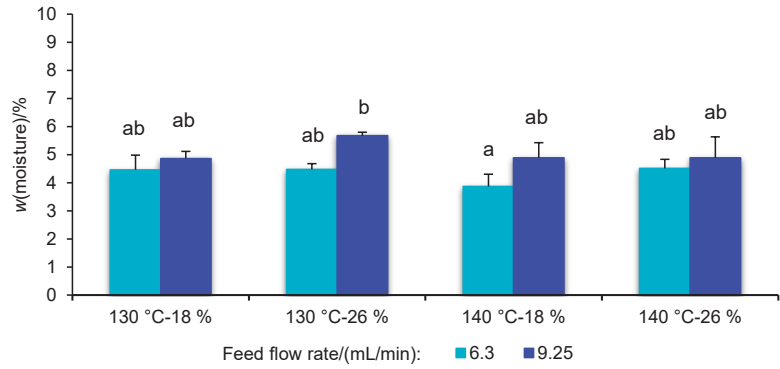

Fig. 1. Moisture content of a dried yeast powder of Rhodotorula mucilaginosa obtained under different spray drying conditions. Different letters indicate highly significant differences at $p<0.01$

with antagonistic activity against $B$. cinerea, $P$. expansum and Rhizopus nigricans, was spray dried, but its survival rate was below $20 \%$ in both cases (Table 2), therefore it was concluded that this yeast strain was inappropriate for the production of economically viable dehydrated product. On the other hand, Romano et al. (35) applied $3 \%$ skimmed milk as a protective agent during spray drying of wine industry yeast Saccharomyces cerevisiae and achieved a survival rate of $62.4 \%$ at inlet and outlet temperatures of 120 and $60^{\circ} \mathrm{C}$, respectively. On the contrary, Chandralekha et al. (48) achieved survival rates over 80.5 $\%$ during spray drying of S. cerevisiae, but with $10 \%$ maltodextrin as encapsulating agent at inlet and outlet temperatures of 100 and $65^{\circ} \mathrm{C}$ respectively. These studies indicate the positive protective effect of an encapsulating agent on the survival rate during spray drying. Aponte et al. (47) investigated spray drying of S. cerevisiae with $3.5 \%$ starch and $1.75 \%$ maltose as protective agents at inlet and outlet air temperatures of 110 and 55 ${ }^{\circ} \mathrm{C}$, respectively. A higher survival rate (Table 2 ) was achieved with maltodextrin than with starch and maltose, which would indicate its better suitability for use as a protective encapsulating agent. However, the efficacy of maltodextrin as protective agent is not proportional to its quantity. In this study a higher survival rate was achieved with $18 \%$ maltodextrin and it decreased at the same feed flow rate and inlet temperature when maltodextrin mass per volume ratio was increased to $26 \%$.

Table 1. Effect of independent variables (maltodextrin mass per volume ratio, feed flow rate and inlet air temperature) on the outlet air temperature and survival rate of Rhodotorula mucilaginosa

\begin{tabular}{|c|c|c|c|c|c|}
\hline \multirow{2}{*}{$\begin{array}{l}(m(\text { maltodextrin)/ } \\
V(\text { suspension })) / \%\end{array}$} & \multirow{2}{*}{$\begin{array}{l}\text { Feed flow rate/ } \\
(\mathrm{mL} / \mathrm{min})\end{array}$} & \multicolumn{2}{|c|}{ Temperature $/{ }^{\circ} \mathrm{C}$} & \multirow{2}{*}{$\begin{array}{l}\text { Yeast survival } \\
\text { rate**/\% }\end{array}$} & \multirow{2}{*}{$\log \left(N_{\mathrm{p}} / N_{\mathrm{s}}\right)^{* *}$} \\
\hline & & Inlet air & Outlet air* & & \\
\hline 18 & 6.3 & 130 & $(73.3 \pm 2.3)^{\mathrm{de}}$ & $(3.4 \pm 0.3)^{\mathrm{e}}$ & $(-1.47 \pm 0.04)^{f}$ \\
\hline 26 & 6.3 & 130 & $(73.3 \pm 0.6)^{\mathrm{de}}$ & $(15.2 \pm 1.4)^{d}$ & $(-0.82 \pm 0.04)^{d}$ \\
\hline 18 & 6.3 & 140 & $(76.3 \pm 1.5)^{\mathrm{de}}$ & $(0.7 \pm 0.2)^{f}$ & $(-2.2 \pm 0.1)^{g}$ \\
\hline 26 & 6.3 & 140 & $(77.0 \pm 1.0)^{\mathrm{e}}$ & $(0.5 \pm 0.0)^{f}$ & $(-2.33 \pm 0.01)^{\mathrm{h}}$ \\
\hline 18 & 9.25 & 130 & $(62.0 \pm 1.0)^{\mathrm{a}}$ & $(113.6 \pm 6.7)^{a}$ & $(0.05 \pm 0.03)^{\mathrm{a}}$ \\
\hline 26 & 9.25 & 130 & $(64.3 \pm 2.1)^{\mathrm{ab}}$ & $(62.9 \pm 13.0)^{\mathrm{b}}$ & $(-0.21 \pm 0.09)^{b}$ \\
\hline 18 & 9.25 & 140 & $(67.7 \pm 1.2)^{\mathrm{bc}}$ & $(31.8 \pm 4.5)^{c}$ & $(-0.50 \pm 0.06)^{c}$ \\
\hline 26 & 9.25 & 140 & $(71.7 \pm 0.6)^{\mathrm{cd}}$ & $(13.0 \pm 1.2)^{d}$ & $(-1.0 \pm 0.2)^{\mathrm{e}}$ \\
\hline
\end{tabular}

*Different letters indicate highly significant differences at $p<0.01$

**Different letters indicate significant differences at $p<0.05$ 
Table 2. Survival rate, moisture content and powder yield for assays with different yeasts and different protective agents

\begin{tabular}{|c|c|c|c|c|c|c|c|}
\hline Yeast & $\begin{array}{l}\text { Temperature } /{ }^{\circ} \mathrm{C} \\
\text { (inlet/outlet air) }\end{array}$ & $\begin{array}{c}w(\text { protective } \\
\text { agent) } / \%\end{array}$ & $\begin{array}{l}\text { Yeast survival } \\
\text { rate/\% }\end{array}$ & $\log \left(N_{\mathrm{p}} / N_{\mathrm{s}}\right)$ & $w($ moisture $) / \%$ & $Y($ yeast powder) $/ \%$ & Ref. \\
\hline Candida sake CPA-1 & 150/n.d. & $\begin{array}{c}\text { skimmed milk } \\
10\end{array}$ & 17.0 & $(-0.79)$ & n.d. & n.d. & $(20)$ \\
\hline Candida sake CPA-1 & $150 / 77.8$ & $\begin{array}{c}\text { skimmed milk } \\
10\end{array}$ & $(8.5)$ & -1.09 & 7.9 & 43.8 & (21) \\
\hline $\begin{array}{l}\text { Saccharomyces } \\
\text { cerevisiae }\end{array}$ & $120 / 60$ & skimmed milk 3 & 62.4 & $(-0.23)$ & n.d. & n.d. & (35) \\
\hline $\begin{array}{l}\text { Saccharomyces } \\
\text { cerevisiae }\end{array}$ & $110 / 55$ & $\begin{array}{c}\text { starch } 3.5 \text { with } \\
\text { maltose } 1.75\end{array}$ & $33.2 / 52.6$ & $-0.3 /-0.5$ & $5.3 / 5.6$ & n.d. & $(47)$ \\
\hline $\begin{array}{l}\text { Saccharomyces } \\
\text { cerevisiae }\end{array}$ & $100 / 65$ & maltodextrin 10 & 80.5 & $(-0.12)$ & 3.2 & 25.8 & $(48)$ \\
\hline
\end{tabular}

n.d.=not determined. Values of survival rate in brackets were calculated according to Eq. 2

In this work, total survival of R. mucilaginosa during spray drying under the above-mentioned conditions was shown to be possible. This may partly be a result of the applied drying conditions as well as of the innate physiological characteristics of the yeast species. It has been observed that the resistance of yeast cells would increase under various types of stress situations as they tend to produce trehalose during the stationary phase $(20,25,26)$. In our study, we determined a high content of trehalose of $169.5 \mathrm{mg} / \mathrm{g}$ in the freeze-dried cells of our cultivated $R$. mucilaginosa. This was much higher than $<20 \mathrm{mg} / \mathrm{g}$ reported for spray-dried C. sake CPA-1, which was also used as a biocontrol agent, but with a survival rate of only $17 \%(20)$.

\section{Moisture content}

Moisture content achieved after spray drying was evaluated by an analysis of variance that showed significant differences between some treatments at a confidence level of $99 \%$ $(\mathrm{p}<0.01)$. Contrary to survival rate, low moisture content (below $10 \%$ ) of the biocontrol yeast powder is necessary to obtain its microbiological stability and prolonged shelf-life (48). The lowest moisture content of $3.9 \%$ was observable at the highest inlet temperature of $140{ }^{\circ} \mathrm{C}$ and lowest feed flow of $6.30 \mathrm{~mL} / \mathrm{min}$ (Fig. 1). However, under these conditions, the survival rate was only $0.7 \%$ (Table 1 ). Using conditions for the best survival rate, as shown in Table 1, a moisture content of $4.9 \%$ was obtained (Fig. 1), which is also favourable for microbiological stability. Abadias et al. (21) considered the moisture content below $8 \%$ for practical applications, so that the survival rate may well serve as criterion to set drying conditions (21).

\section{Yeast powder yield}

In the spray drying assays, yeast powder yield did not significantly $(p>0.05)$ depend on the process parameters. The highest yeast powder yield of $50.3 \%$ (Fig. 2) was observed at an inlet temperature of $140{ }^{\circ} \mathrm{C}$ with $18 \%$ maltodextrin and feed flow rate of $6.30 \mathrm{~mL} / \mathrm{min}$. This may be due to the lowest moisture content of $3.9 \%$ also observed under these conditions, which imparted best flowability of the powder over a glass surface.

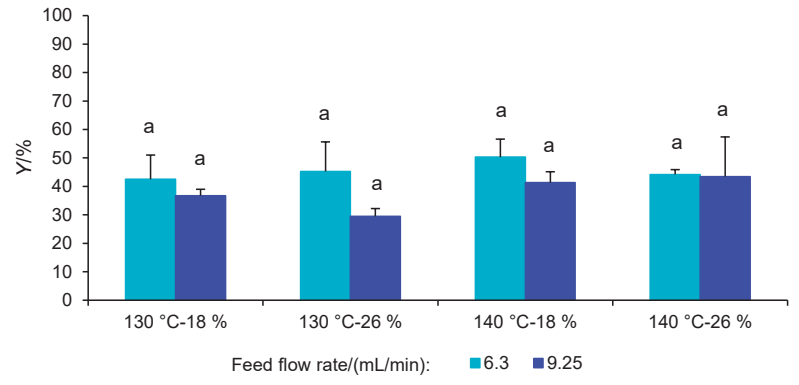

Fig. 2. Yeast powder yield of Rhodotorula mucilaginosa obtained under different spray drying conditions. Different letters indicate significant differences ( $p>0.05$ ) among treatments

On the other hand, under the conditions of best survival rate, the yeast powder yield was only $36.7 \%$. The higher moisture content of $4.9 \%$ could be unfavourable for flow characteristics together with the hygroscopic nature of maltodextrin (48), which may provoke stickiness and higher adhesiveness to the glass surface of the dryer, reducing the yield efficiency. However, in an industrial spray dryer special devices, like hammering devices or electric or mechanic vibrators, are available and they could improve the separation process and increase the yield of yeast powder.

\section{Antagonistic activity of $R$. mucilaginosa against $B$. cinerea}

To further evaluate the antagonistic activity of $R$. mucilaginos $a$ against $B$. cinerea, the dried products with the highest and lowest survival rate were analyzed. The best in vitro antagonistic activity compared with the control sample was observed with the yeast powder obtained at an inlet temperature of $130{ }^{\circ} \mathrm{C}$ with $18 \%$ maltodextrin and a feed flow rate of $9.25 \mathrm{~mL} / \mathrm{min}$ (Fig. 3). Zhang et al. (38) reported similar results after performing an in vitro assay on PDA with $R$. mucilaginosa against $B$. cinerea. However, a cell count of R. mucilaginosa below $10^{8}$ cells $/ \mathrm{mL}$ was used against a cell count $>10^{5}$ spores $/ \mathrm{mL}$ of $B$. cinerea. Moreover, Zhang et al. $(38,44)$ also showed that the reduction of incidence of grey mould disease on strawberries by $R$. mucilaginosa could be further improved using phytic acid or chitosan. In the present study, 


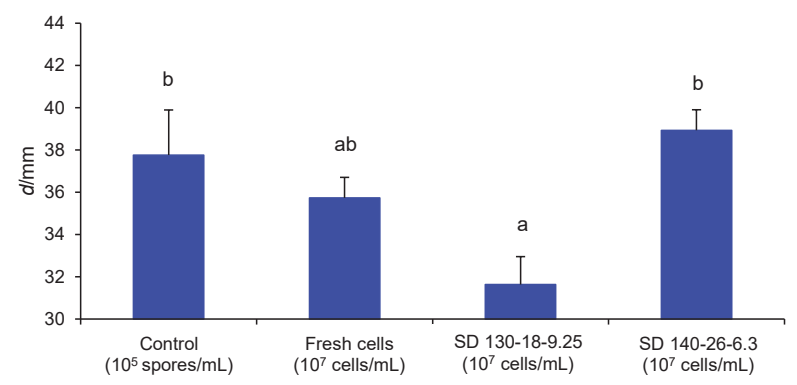

Fig. 3. Antagonistic activity in vitro of the spray-dried (SD) Rhodotorula mucilaginosa compared to that of the fresh yeast cells. Numbers 130-18-9.25 and 140-26-6.3 refer to inlet drying temperature $\left({ }^{\circ} \mathrm{C}\right)$, maltodextrin mass per volume ratio (\%) and feed flow rate $(\mathrm{mL} /$ $\mathrm{min})$. Different letters indicate highly significant differences $(p<0.01)$ among treatments

it was observed that maltodextrin was not only efficient as a shield to increase the cell viability, which was reflected in the high yeast survival rate, but it also improved the antagonistic activity of R. mucilaginosa against B. cinerea. Higher antagonistic activity of spray-dried cells encapsulated with $18 \%$ maltodextrin was observed than of fresh ones (Fig. 3), which may be due to an unreported interaction between $R$. mucilaginosa and maltodextrin. A possible mechanism of action may be related to the effect of maltodextrin as a protective encapsulating agent. It has been reported that the components for biological control like potassium bicarbonate, sodium carbonate and bicarbonate could reduce the turgidity of the fungal cells, impeding sporulation of the phytopathogen fungus $(49,50)$. An increased adherence of maltodextrin to the hyphae of the fungus may also be responsible for curtailing the growth of the phytopathogen fungus (18). Further study of the influence of maltodextrin on the antagonistic activity of R. mucilaginosa should be considered.

The in vivo antagonistic activity was tested (Fig. 4) on wounded apples using the dried cells of $R$. mucilaginosa $\left(10^{7}\right.$ cells $/ \mathrm{mL}$ ) that achieved a survival rate of $100 \%$ during spray drying at $130{ }^{\circ} \mathrm{C}$ inlet temperature, $18 \%$ maltodextrin and a flow rate of $9.25 \mathrm{~mL} / \mathrm{min}$. As shown in Fig. 4, the biocontrol efficacy of $R$. mucilaginosa $\left(10^{7}\right.$ cells $\left./ \mathrm{mL}\right)$ was significantly

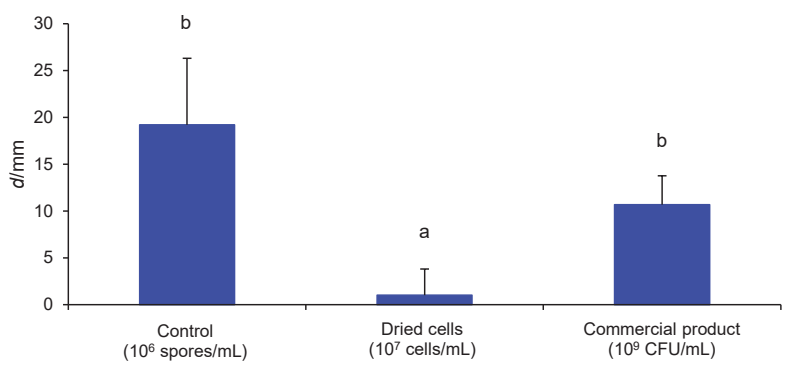

Fig. 4. Antagonistic activity in vivo of the spray dried Rhodotorula mucilaginosa on wounded apples compared to that of the commercial product (Trichonativa). Different letters indicate significant differences $(p<0.05)$ among treatments higher $(\mathrm{p}<0.05)$ than that of the commercial product containing Trichoderma spp. $\left(10^{9} \mathrm{CFU} / \mathrm{mL}\right)$ as biocontrol agent; the control sample with $10^{6} \mathrm{spore} / \mathrm{mL}$ also showed a significantly $(p<0.05)$ lower biocontrol efficacy. The spray-dried R. mucilaginosa inhibited grey mould growth by $94.8 \%$ compared to the commercial biocontrol agent that inhibited the growth by only $44.4 \%$. The growth inhibition was the ratio of the difference in lesion diameter of the treated and control samples to the lesion diameter of control sample, expressed as a percentage. Similar results have been reported by Liu et al. (16) for in vivo antagonistic activity of fresh cells of C. oleophila $\left(10^{7}\right.$ cells $/ \mathrm{mL}$ ) on apples, with a significant reduction of the wound diameter compared to the control with $10^{4}$ spores $/ \mathrm{mL}$.

\section{CONCLUSIONS}

An antagonistic yeast identified as Rhodotorula mucilaginosa belongs to the natural surface microbiota of murta (Ugni molinae Turcz) berries and acts as a protection against the phytopathogen fungus Botrytis cinerea. The performed spray drying assays have shown that it is possible to obtain a dried yeast powder of $R$. mucilaginosa that retains a survival rate of $100 \%$, using an inlet temperature of $130{ }^{\circ} \mathrm{C}$ with $18 \%$ maltodextrin as encapsulating agent at a feed flow rate of $9.25 \mathrm{~mL} /$ min. The spray drying process can produce a yeast powder with a moisture content below $8 \%$, necessary for practical application, with improved in vitro antagonistic activity compared to the fresh yeast cells, as well as an in vivo antagonistic activity with an inhibition rate of $94.8 \%$ on grey mould spoilage in apples. The use of maltodextrin may also be effective in improving the in vitro antagonistic activity of R. mucilaginosa.

\section{ACKNOWLEDGEMENTS}

The authors gratefully acknowledge financial support provided by National Commission for Scientific and Technological Development (CONICYT), Chile, through scholarship granted to A. González-Esparza.

\section{ORCID IDs}

A. González-Esparza (1) https://orcid.org/0000-0002-5903-2125 J.C. Gentina (1) https://orcid.org/0000-0002-1265-9828 K.S. Ah-Hen (1) https://orcid.org/0000-0003-4595-0707 R. Alvarado (1) https://orcid.org/0000-0001-9811-4855

J. Stevenson (1) https://orcid.org/0000-0002-1356-6658

E. Briceño (1) https://orcid.org/0000-0003-4086-4439

O. Montenegro (D) https://orcid.org/0000-0002-6801-6215

\section{REFERENCES}

1. Williamson B, Tudzynski B, Tudzynski P, Van Kan JA. Botrytis cinerea: The cause of grey mould disease. Mol Plant Pathol. 2007;8(5):561-80.

https://doi.org/10.1111/j.1364-3703.2007.00417.x

2. Romanazzi G, Feliziani E. Botrytis cinerea (gray mold). In: Bautista-Baños S, editor. Postharvest decay: Control strategies. 
Cambridge, MA, USA: Academic Press, Elsevier B.V.; 2014. pp. 131-46.

https://doi.org/10.1016/B978-0-12-411552-1.00004-1

3. Romanazzi G, Smilanick JL, Feliziani E, Droby S. Integrated management of postharvest gray mold on fruit crops. Postharvest Biol Technol. 2016;113:69-76.

https://doi.org/10.1016/j.postharvbio.2015.11.003

4. Junaid JM, Dar NA, Bhat TA, Bhat AH, Bhat MA. Commercial biocontrol agents and their mechanism of action in the management of plant pathogens. Int J Modern Plant Anim Sci. 2013;1(2):39-57.

5. Spadaro D, Gullino ML. State of the art and future prospects of the biological control of postharvest fruit diseases. Int J Food Microbiol. 2004;91(2):185-94. https://doi.org/10.1016/S0168-1605(03)00380-5

6. Sundh I, Goettel MS. Regulating biocontrol agents: A historical perspective and a critical examination comparing microbial and macrobial agents. Biocontrol. 2012;58(5):575-93. https://doi.org/10.1007/s10526-012-9498-3

7. Leroux P, Fritz R, Debieu D, Albertini C, Lanen C, Bach J, et al. Mechanisms of resistance to fungicides in field strains of Botrytis cinerea. Pest Manag Sci. 2002;58(9):876-88. https://doi.org/10.1002/ps.566

8. Janisiewicz WJ, Korsten L. Biological control of postharvest diseases of fruits. Annu Rev Phytopathol. 2002;40:411-41. https://doi.org/10.1146/annurev.phyto.40.120401.130158

9. Benítez T, Rincón AM, Limón MC, Codón AC. Biocontrol mechanisms of Trichoderma strains. Int Microbiol. 2004;7(4): 249-60.

10. Fravel DR. Commercialization and implementation of biocontrol. Annu Rev Phytopathol. 2005;43:337-59. https://doi.org/10.1146/annurev.phyto.43.032904.092924

11. Droby S, Wisniewski M, Macarisin D, Wilson C. Twenty years of postharvest biocontrol research: Is it time for a new paradigm? Postharvest Biol Technol. 2009;52(2):137-45. https://doi.org/10.1016/j.postharvbio.2008.11.009

12. Vincent $C$, Goettel M, Lazarovits $G$, editors. Biological control: A global perspective. Wallingford, UK: CABI; 2007.

13. Liu J, Sui Y, Wisniewski M, Droby S, Liu Y. Review: Utilization of antagonistic yeasts to manage postharvest fungal diseases of fruit. Int J Food Microbiol. 2013;167(2):153-60. https://doi.org/10.1016/j.jfoodmicro.2013.09.004

14. Spadaro D, Ciavorella A, Dianpeng Z, Garibaldi A, Gullino ML. Effect of culture media and $\mathrm{pH}$ on the biomass production and biocontrol efficacy of a Metschnikowia pulcherrima strain to be used as a biofungicide for postharvest disease control. Can J Microbiol. 2010; 56(2):128-37. https://doi.org/10.1139/W09-117

15. Liu J, Wisniewski M, Droby S, Tian S, HershkovitzV, Tworkoski T. Effect of heat shock treatment on stress tolerance and biocontrol efficacy of Metschnikowia fructicola. FEMS Microbiol
Ecol. 2011;76(1):145-55.

https://doi.org/10.1111/j.1574-6941.2010.01037.x

16. Liu J, Wisniewski M, Droby S, Norelli J, Hershkovitz V, Tian $\mathrm{S}$, Farrell R. Increase in antioxidant gene transcripts, stress tolerance and biocontrol efficacy of Candida oleophila following sublethal oxidative stress exposure. FEMS Microbiol Ecol. 2012;80(3):578-90.

https://doi.org/10.1111/j.1574-6941.2012.01324.x

17. Sui Y, Liu J. Effect of glucose on thermotolerance and biocontrol efficacy of the antagonistic yeast Pichia guilliermondii. Biol Control. 2014;74:59-64.

https://doi.org/10.1016/j.biocontrol.2014.04.003

18. Zhou Y, Zhang L, Zeng K. Efficacy of Pichia membranaefaciens combined with chitosan against Colletotrichum gloeosporioides in citrus fruits and possible modes of action. Biol Control. 2016;96:39-47.

https://doi.org/10.1016/j.biocontrol.2016.02.001

19. Spadaro D, Droby S. Development of biocontrol products for postharvest diseases of fruit: The importance of elucidating the mechanisms of action of yeast antagonists. Trends Food Sci Technol. 2016;47:39-49.

https://doi.org/10.1016/j.tifs.2015.11.003

20. Cañamas TP, Viñas I, Usall J, Magan N, Solsona C, Teixidó N. Impact of mild heat treatments on induction of thermotolerance in the biocontrol yeast Candida sake CPA-1 and viability after spray-drying. J Appl Microbiol. 2008;104(3):767-75. https://doi.org/10.1111/j.1365-2672.2007.03590.x

21. Abadias M, Teixidó N, Usall J, Solsona C, Viñas I. Survival of the postharvest biocontrol yeast Candida sake CPA-1 after dehydration by spray-drying. Biocontrol Sci Techn. 2005; 15(8):835-46.

https://doi.org/10.1080/09583150500187041

22. Abadias M, Benabarre A, Teixidó N, Usall J, Viñas I. Effect of freeze drying and protectants on viability of the biocontrol yeast Candida sake. Int J Food Microbiol. 2001;65(3):173-82. https://doi.org/10.1016/S0168-1605(00)00513-4

23. Melin $\mathrm{P}$, Håkansson $\mathrm{S}$, Schnürer J. Optimisation and comparison of liquid and dry formulations of the biocontrol yeast Pichia anomala J121. Appl Microbiol Biotechnol. 2007; 73(5):1008-16.

https://doi.org/10.1007/s00253-006-0552-x

24. Melin P, Schnürer J, Håkansson S. Formulation and stabilisation of the biocontrol yeast Pichia anomala. Antonie Van Leeuwenhoek. 2011;99(1):107-12.

https://doi.org/10.1007/s10482-010-9522-5

25. Li BQ, Tian SP. Effects of trehalose on stress tolerance and biocontrol efficacy of Cryptococcus laurentii. J Appl Microbiol. 2006;100(4):854-61.

https://doi.org/10.1111/j.1365-2672.2006.02852.x

26. Li BQ, Zhou ZW, Tian SP. Combined effects of endo- and exogenous trehalose on stress tolerance and biocontrol efficacy 
of two antagonistic yeasts. Biol Control. 2008;46(2):187-93. https://doi.org/10.1016/j.biocontrol.2008.04.011

27. Dunlap CA, Schisler DA. Fluidized-bed drying and storage stability of Cryptococcus flavescens $\mathrm{OH}$ 182.9, a biocontrol agent of Fusarium head blight. Biocontrol Sci Technol. 2010; 20(5):465-74.

https://doi.org/10.1080/09583150903572377

28. Mounir R, Durieux A, Bodo E, Allard C, Simon JP, Achbani $\mathrm{EH}$, et al. Production, formulation and antagonistic activity of the biocontrol like-yeast Aureobasidium pullulans against Penicillium expansum. Biotechnol Lett. 2007;29(4):553-9.

https://doi.org/10.1007/s10529-006-9269-2

29. Silva J, Freixo R, Gibbs P, Teixeira P. Spray-drying for the production of dried cultures. Int J Dairy Technol. 2011;64(3):321-35. https://doi.org/10.1111/j.1471-0307.2011.00677.x

30. Gharsallaoui A, Roudaut G, Chambin O, Voilley A, Saurel R. Applications of spray-drying in microencapsulation of food ingredients: An overview. Food Res Int. 2007;40(9):1107-21. https://doi.org/10.1016/j.foodres.2007.07.004

31. Peighambardoust SH, Golshan Tafti A, Hesari J. Application of spray drying for preservation of lactic acid starter cultures: a review. Trends Food Sci Technol. 2011;22(5):215-24. https://doi.org/10.1016/j.tifs.2011.01.009

32. Schuck P, Dolivet A, Méjean S, Hervé $C$, Jeantet R. Spray drying of dairy bacteria: New opportunities to improve the viability of bacteria powders. Int Dairy J. 2012;31(1):12-7. https://doi.org/10.1016/j.idairyj.2012.01.006

33. Corcoran BM, Ross RP, Fitzgerald GF, Stanton C. Comparative survival of probiotic lactobacilli spray-dried in the presence of prebiotic substances. J Appl Microbiol. 2004; 96(5):1024-39. https://doi.org/10.1111/j.1365-2672.2004.02219.x

34. Petrović T, Nedović V, Dimitrijević-Brancović S, Bugarski B, Lacroix C. Protection of probiotic microorganisms by microencaptulation. Chem Ind Chem Eng Q. 2007;13(3):169-74. https://doi.org/10.2298/CICEQ0703169P

35. Romano P, Pietrafesa R, Romaniello R, Zambuto M, Calabretti A, Capece A. Impact of yeast starter formulations on the production of volatile compounds during wine fermentation. Yeast. 2015;28(1):245-56.

https://doi.org/10.1002/yea.3034

36. Benson DA, Karsch-Mizrachi I, Lipman DJ, Ostell J, Wheeler DL. GenBank. Nucleic Acids Res. 2008;36(Suppl. 1):D25-30. https://doi.org/10.1093/nar/gkm929

37. Altschul SF, Gish W, Miller W, Myers EW, Lipman DJ. Basic local alignment search tool. J Mol Biol. 1990;215(3):403-10. https://doi.org/10.1016/S0022-2836(05)80360-2

38. Zhang $H$, Yang $Q$, Lin $H$, Ren $X$, Zhao L, Hou J. Phytic acid enhances biocontrol efficacy of Rhodotorula mucilaginosa against postharvest gray mold spoilage and natural spoilage of strawberries. LWT - Food Sci Technol. 2013;52(2):110-5. https://doi.org/10.1016/j.lwt.2012.01.027
39. Sharma RR, Singh D, Singh R. Biological control of postharvest diseases of fruits and vegetables by microbial antagonists: A review. Biol Control. 2009;50(3):205-21.

https://doi.org/10.1016/j.biocontrol.2009.05.001

40. Cheng Z, Chi M, Li G, Chen H, Sui Y, Sun H, et al. Heat shock improves stress tolerance and biocontrol performance of Rhodotorula mucilaginosa. Biol Control. 2016;95:49-56.

https://doi.org/10.1016/j.biocontrol.2016.01.001

41. Gholamnejad J, Etebarian HR, Sahebani N. Biological control of apple blue mold with Candida membranifaciens and Rhodotorula mucilaginosa. Afr J Food Sci. 2010;4(1):1-7.

42. Hu H, Yan F, Wilson C, Shen Q, Zheng X. The ability of a cold-adapted Rhodotorula mucilaginosa strain from Tibet to control blue mold in pear fruit. Antonie van Leeuwenhoek. 2015;108(6):1391-404.

https://doi.org/10.1007/s10482-015-0593-1

43. Zhang H, Liu Z, Xu B, Chen K, Yang Q, Zhang Q. Burdock fructooligosaccharide enhances biocontrol of Rhodotorula mucilaginosa to postharvest decay of peaches. Carbohydr Polym. 2013;98(1):366-71.

https://doi.org/10.1016/j.carbpol.2013.06.008

44. Zhang H, Ge L, Chen K, Zhao L, Zhang X. Enhanced biocontrol activity of Rhodotorula mucilaginosa cultured in media containing chitosan against postharvest diseases in strawberries: Possible mechanisms underlying the effect. J Agric Food Chem. 2014;62(18):4214-24.

https://doi.org/10.1021/jf500065n

45. Zhang H, Yang Q, Ge L, Zhang G, Zhang X, Zhang X. Chitin enhances biocontrol of Rhodotorula mucilaginosa to postharvest decay of peaches. Int J Biol Macromol. 2016; 88:465-75. https://doi.org/10.1016/j.ijbiomac.2016.04.014

46. Santivarangkna C, Kulozik U, Foerst P. Alternative drying processes for the industrial preservation of lactic acid starter cultures. Biotechnol Progr. 2007;23(2):302-15.

https://doi.org/10.1021/bp060268f

47. Aponte M, Troianiello GD, Di Capua M, Romano R, Blaiotta G. Impact of different spray-drying conditions on the viability of wine Saccharomyces cerevisiae strains. World J Microbiol Biotechnol. 2016;32:13.

https://doi.org/ 10.1007/s11274-015-1956-5

48. Chandralekha A, Hrishikesh Tavanandi A, Amrutha N, Umesh Hebbar H, Raghavarao KSMS, Gadre R. Encapsulation of yeast (Saccharomyces cerevisiae) by spray drying for extension of shelf life. Dry Technol. 2016;31(11):1307-18. https://doi.org/10.1080/07373937.2015.1112808

49. Fallir E, Grinberg S, Ziv O. Potassium bicarbonate reduces postharvest decay development on bell pepper fruits. J Hortic Sci. 1997;72(1):35-41. https://doi.org/10.1080/14620316.1997.11515489

50. Youssef K, Sanzani SM, Ligorio A, Ippolito A, Terry LA. Sodium carbonate and bicarbonate treatments induce resistance to postharvest green mould on citrus fruit. Postharvest Biol Technol. 2014.87:61-9.

https://doi.org/10.1016/j.postharvbio.2013.08.006 